\title{
Factors affecting mortality of shearwaters stranded by light pollution
}

\author{
A. Rodríguez ${ }^{1}$, B. Rodríguez ${ }^{2}$, Á. J. Curbelo ${ }^{3,4}$, A. Pérez ${ }^{3,4}$, S. Marrero ${ }^{3,4}$ \& J. J. Negro ${ }^{1}$ \\ 1 Department of Evolutionary Ecology, Estación Biológica de Doñana (CSIC), Seville, Spain \\ 2 La Malecita S/N, Buenavista del Norte, Canary Islands, Spain \\ 3 Grupo de Pronto Auxilio de Arafo (GPA), Arafo, Canary Islands, Spain \\ 4 Asociación Tinerfeña de la Naturaleza (ATINA), Güímar, Canary Islands, Spain
}

\section{Keywords}

body condition; Calonectris diomedea;

Canary Islands; illumination; light pollution;

mortality; sex ratio.

\section{Correspondence}

Airam Rodríguez, Department of Evolutionary Ecology, Estación Biológica de Doñana (CSIC), Avda. Américo Vespucio s/n, 41092 Seville, Spain.

Email: airamrguez@ebd.csic.es

Editor: Todd Katzner

\begin{abstract}
Every year and across the world, thousands of fledglings of different petrel species crash into human structures because they are disorientated by artificial lights during their first flights. As this phenomenon is rather predictable, rescue campaigns are organized to help birds to reach the ocean, but unfortunately, a low proportion gets hurt or dies. Despite the huge number of affected individuals, and the fact that the problem was detected a long time ago, little is known on this source of mortality. We have studied the factors (i.e. body condition, plumage development, fledging date and sex) influencing the mortality of Cory's Shearwater Calonectris diomedea fledglings stranded inland due to light pollution in Tenerife (Canary Islands) during two consecutive breeding seasons (2009 and 2010). Late fledglings showed lower values of a body condition index than early ones. No sex biases were detected, neither considering stranded birds overall, nor for recovery dates or in the body condition of rescued fledglings. Our results indicate that late birds stranded by lights showing abundant down are more susceptible to fatal collisions and that the lights do not selectively kill birds with lower body condition indices. An enhancement of veterinary care should be done during the last part of the fledging period when more fatal collisions occur, especially focused on fledglings with abundant down. More research to determine why some individuals end up disoriented around artificial lights and others do not is urgently needed to minimize or prevent fallouts.
\end{abstract}

\section{Introduction}

Light pollution has been suggested to have an important impact on ecosystems, inducing physiological and behavioural changes in animals, as well as mass mortality episodes for certain species (Longcore \& Rich, 2004; Stone, Jones \& Harris, 2009; Kempenaers et al., 2010). Already identified as an area of interest for biodiversity conservation, the effect of light pollution on organisms is far from being understood (Rich \& Longcore, 2006; Hölker et al., 2010a,b). Disentangling the implications of this source of environmental stress may be necessary to reduce mortality for numerous nocturnal species and threatened populations of different taxa, including birds, sea turtles and numerous insects (Jones \& Francis, 2003; Rich \& Longcore, 2006; Poot et al., 2008; Bourgeois et al., 2009).

In the case of petrels (including shearwaters and storm petrels), thousands of fledglings are attracted to lights every year during their first flights from their nests to the open ocean worldwide (Telfer et al., 1987; Le Corre et al., 2002; Rodríguez \& Rodríguez, 2009; Miles et al., 2010; Fontaine,
Gimenez \& Bried, 2011). This phenomenon, known for a long time (Imber, 1975 and references therein), is termed 'fallout' (Reed, Sincock \& Hailman, 1985; Ainley et al., 2001). Thanks to rescue campaigns involving the general public, non-government organizations and local authorities, the majority of rescued birds (more than 90\%) are released back to the wild, although some casualties occur by starvation, dehydration, predation or road casualties in the short term (Telfer et al., 1987; Ainley et al., 2001; Le Corre et al., 2002; Rodríguez \& Rodríguez, 2009; Miles et al., 2010; Fontaine et al., 2011). In addition, the accumulation of data on rescue campaigns provides basic life-history information useful for the conservation and appropriate management of secretive and rare petrels (e.g. Ainley et al., 2001; Le Corre et al., 2003; Rodríguez et al., 2008; Duffy, 2010; Rodríguez, Rodríguez \& Lucas, 2012).

An appropriate knowledge of basic population traits, such as condition and sex ratio, and its relationship with demography, behaviour and population persistence contributes to effective management programs of threatened species (Tella, 2001; Donald, 2007; Ferrer, Newton \& 
Pandolfi, 2009). For example, the male-biased sex ratio of the critically endangered kakapo Strigops habroptilus was a challenge to its recovery. Based on the sex-allocation theory, a decrease of maternal condition has led to an unbiased offspring sex ratio (see Robertson et al., 2006). Despite the fact that rescue campaigns that aim to reduce the artificial light-induced mortality would easily provide data on sex ratio and body condition of rare and threatened petrel populations, no studies have assessed this topic yet.

In this study, we used data from Cory's Shearwater Calonectris diomedea rescue campaigns carried out in Tenerife (Canary Islands) during 2 years to assess the general body condition and sex ratio of fallout. Our first specific goal was to assess body condition of fledglings attracted to lights throughout the fledging period, taking into account gender, year, bird status (successfully released/dead) and/or plumage characteristics (abundance of down). Parental food delivery and feeding frequency decrease sharply at the end of chick-rearing period in petrels (Warham, 1990), and on full-moon nights (Klomp \& Furness, 1992; Riou \& Hamer, 2008; but see also Granadeiro, Burns \& Furness, 1998; Granadeiro et al., 2009; Mougin, Jouanin \& Roux, 2000a). The majority of petrel species are sexually size dimorphic, males being larger and heavier than females and, consequently, more sensitive to adverse conditions (Cockburn, Legge \& Double, 2002; Kalmbach \& Benito, 2007). Considering the above, we predicted that rescued male fledglings would be in worse body condition than females, especially at later fledging stage and during the years when full moon coincides with the fledging period.

Our second specific goal was to determine whether the number of affected birds and the seasonal pattern of fallouts were sex biased. As a consequence of the predicted worse body condition of fledgling males, we would expect a malebiased sex ratio, especially in fallouts coinciding with full moon. Given the high philopatry exhibited by petrels (Warham, 1990), a sex-biased attraction might impose additional conservation costs of this increasing human-induced source of mortality to the affected populations (particularly if the rescue efforts were less successful than it is estimated).

Our final goal was to determine what factors may explain the fate of rescued birds, that is, comparing individuals released back into the wild versus the ones found dead or too injured to be released. Given the limited funds destined to management and conservation tasks, identifying these factors may be useful to improve rescue campaign designs for Cory's Shearwaters in the Canary Islands and other petrel species elsewhere.

\section{Material and methods}

\section{Model species}

The Cory's Shearwater C. diomedea is a medium-sized seabird (body mass, 600-800 g; wingspan, 112-126 cm). It breeds in Atlantic (Azores, Berlenga, Madeira, Selvagem and Canary Islands; borealis subspecies) and Mediterranean islands (diomedea subspecies) (Thibault, Bretagnolle \&
Rabouam, 1997). Cory's Shearwaters arrive to their breeding grounds in March from their wintering areas located mainly in the South Atlantic Ocean (see González-Solís et al., 2007). Females lay a single egg per clutch in early June and thus only up to one individual may fledge per nest and per year during late October to early November. This species is sexually dimorphic, a fact evident from the early stages of development, with the males being larger and heavier than females (Thibault et al., 1997). However, equal rearing costs have been suggested for both sexes, and an unbiased sex ratio of offspring at nest has been recorded in Mediterranean breeding colonies (Genovart et al., 2005; but see Bretagnolle \& Thibault, 1995).

In the Canary Islands (but also in other areas such as Azores, Madeira or Mediterranean archipelagos; Baccetti, Sposimo \& Giannini, 2005; Fontaine et al., 2011; Rodrigues et al., 2012), fledglings are strongly attracted to artificial night lights. In Tenerife, the largest of the Canary Islands, between 45 and $61 \%$ of fledglings, is estimated to be affected by artificial light attraction (an average of 993 ! 217 fledglings are annually rescued; Rodríguez \& Rodríguez, 2009), although a steady increase has been documented since 1990, when rescue campaigns were first organized. This increase runs in parallel to the increase of electricity consumption in the island (Rodríguez et al., 2012).

\section{Study area and rescue campaigns}

Tenerife (2034 $\mathrm{km}^{2}$ and up to $3718 \mathrm{~m}$ above sea level) is situated in the central part of the Canary Archipelago $\left(27^{\circ} 37^{\prime}-29^{\circ} 25^{\prime} \mathrm{N}, 13^{\circ} 20^{\prime}-18^{\circ} 19^{\prime} \mathrm{W}\right)$. Approximately 900000 people inhabit Tenerife (ISTAC, 2011), and the majority of whom are concentrated along the coast. The main study site is located in the Valle de Güímar, southeast Tenerife (although we also present data from the whole of Tenerife; see below). This area covers $70 \mathrm{~km}^{2}$, and the landscape is mainly composed of terraced agricultural fields growing different cultivations, loose urban areas as well as small industrial areas. The coastline is dominated by cliffs and rocky boulder shores, where many human settlements are present. Four municipalities (El Rosario, Candelaria, Arafo and Güímar) total approximately 48000 inhabitants (ISTAC, 2011).

The public was requested to rescue stranded birds through awareness campaigns involving local media, seminars in primary and high schools, and distribution of posters, stickers and T-shirts. Birds were collected by Grupo de Pronto Auxilio de Arafo staff and examined for the subsequent release. Injured birds were handed over to a wildlife rehabilitation centre (WRC) sponsored by the local government (La Tahonilla, Cabildo Insular de Tenerife) and held for rehabilitation or euthanized (see details in Rodríguez \& Rodríguez, 2009). During rescue campaigns, fewer than $6 \%$ of birds were found dead or euthanized (Rodríguez \& Rodríguez, 2009). To obtain an adequate sample size of fledglings fatally stranded, we included all birds collected in the whole of Tenerife Island by La Tahonilla staff. The Güímar birds, dead or alive, plus dead 


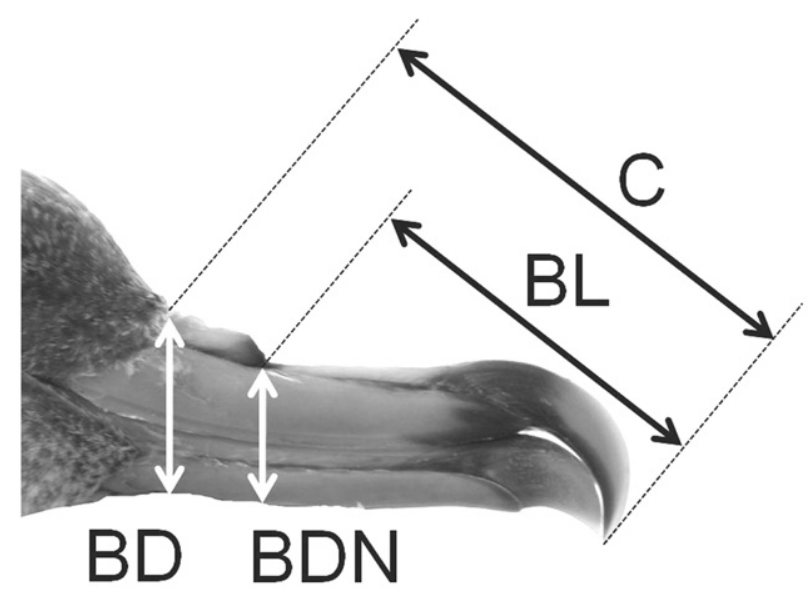

Figure 1 Bill morphometric measurements taken in this study (C, culmen; BL, bill length; BD, bill depth; BDM, bill depth at nostril).

birds from the remaining of Tenerife, were the ones that we measured and sexed in this study.

\section{Moon phase}

Our study was conducted during two consecutive years (2009 and 2010) differing in the moon cycle. Thus, during 2009 fallout, full moon coincided with the mean fledging date of Cory's Shearwater (4 November; Rodríguez \& Rodríguez, 2009), while in 2010, full moon did not affect the fallout (dates of full moon were 2 November in 2009, and 23 October and 21 November in 2010).

\section{Morphological measurements}

For every rescued fledgling, date, recovery location, body mass, wing length (W), tarsus length $(\mathrm{T})$ and four bill morphometric measurements were registered. Bill measurements were culmen (C), from the base of forehead feathers in centre of nasal tube to distant part of the curve of the hooked bill; bill length at nostril (BL), from centre of dorsomedial part of tube to distant part of the curve of the hooked bill; bill depth (BD), from of base of forehead feathers to ventral surface of lower mandible; and bill depth at nostril (BDN), from the base of nasal tube at nostrils to ventral surface of bill (see Fig. 1). The biometrics were taken using a spring balance (nearest $10 \mathrm{~g}$ ), a rule (nearest $1 \mathrm{~mm}$ ) and a electronic calliper (nearest $0.01 \mathrm{~mm}$ ). The presence of down in the head and belly was assessed in an ordinal scale ( 1 = absence and 3 = wholly covered by down), and the sum of the two values (head and belly) was used as an index of down, ranging from 2 (down absence) to 6 (head and belly wholly covered by down).

A body condition index (BCI) for fledglings was calculated as the standardized residuals of an ordinary least square regression between body mass on body size index (BSI). To avoid spurious relationships of BCI, we checked the key assumptions proposed by Green (2001) and fol- lowed his recommendations. Thus, we used the first principal component of a principal component analysis (PCA), including six morphometric measurements (W, T, C, BL, $\mathrm{BD}$ and BDN; see 'statistical analysis' for details), as a BSI. In addition, we tested the linearity of the functional relationship between body mass and our BSI (Pearson correlation, $r=0.609, P<0.001$; linear regression, $F_{1,271}=159.6$, $P<0.001$ ), and the standardized residuals showed low correlations with the separate morphometric measurements (all $r<0.269$ ). Finally, we used 35 freshly dead Cory's Shearwater fledglings to assess the relationship between fat stores and BCI. Specifically, we weighed fat located around the digestive tube and obtained a significant positive relationship ( $r=0.722, P<0.001$ ). Recently, the scaled mass index has been proposed as a more reliable BCI (Peig \& Green, 2009, 2010); however, this index showed a lower $r$-value $(r=0.517, P=0.001)$.

\section{Molecular sex determination}

Two covert feathers on the belly were collected from each bird as a source of DNA for molecular analysis. The base of the feathers was used to extract the DNA (see Horváth et al., 2005) according to the HotShot protocol (Truett, 2006). We sexed 196 fledglings by polymerase chain reaction (PCR) amplification of CHD genes using primers 2550F and 2718R (Fridolfsson \& Ellegren, 1999). PCR was performed in a final volume of $25 \mathrm{~mL}$ containing $3.5 \mathrm{mM}$ $\mathrm{MgCl}_{2}$, $1 ¥$ reaction buffer, $0.02 \%$ gelatin, $0.2 \mathrm{mM}$ each dNTP, $0.2 \mathrm{mM}$ each primer, and $0.04 \mathrm{U} \mathrm{mL}^{-1}$ of Taq DNA polymerase. The PCR profile consisted of 34 cycles of $30 \mathrm{~s}$ at $92^{\circ} \mathrm{C}, 30 \mathrm{~s}$ at $50^{\circ} \mathrm{C}, 45 \mathrm{~s}$ at $72^{\circ} \mathrm{C}$ and, finally, $5 \mathrm{~min}$ at $72^{\circ} \mathrm{C}$. PCR products were run out in an agarose gel (2\%) by electrophoresis. Gels having a single PCR product ( 550 bp) scored as males, while gels having two PCR products of $\sim 550$ bp and $\sim 450$ bp scored as females.

\section{Statistical analysis}

A PCA was used to reduce the number of morphometric measurements from six to one factor (eigenvalues $>1$ ). Bartlett's sphericity test $\left(c^{2}=970.9\right.$, degrees of freedom $=15$, $P<0.001)$ and Kaiser-Meyer-Olkin (KMO) measure $(0.72)$ indicated the adequacy of the correlation matrix. The first factor retained $58.8 \%$ of the original variance and reached an eigenvalue of 3.525. Given that all morphometric measurements showed high and positive factor loadings $(\mathrm{W}=0.631, \mathrm{~T}=0.653, \mathrm{C}=0.847, \mathrm{BL}=0.791, \mathrm{BD}=0.844$ and $\mathrm{BDN}=0.800$ ) to the first principal component, it was considered as a BSI.

We built a discriminant function analysis to determine the gender of fledglings with no genetic material (for procedures, see Supporting Information Appendix S1). Chisquare and likelihood ratio tests were employed to test differences in the sex ratio of grounded fledglings between fallout seasons (2009 and 2010) and status (released vs. dead), as well as in the down index between sexes and years. To assess the variation of BCI throughout the fallout 


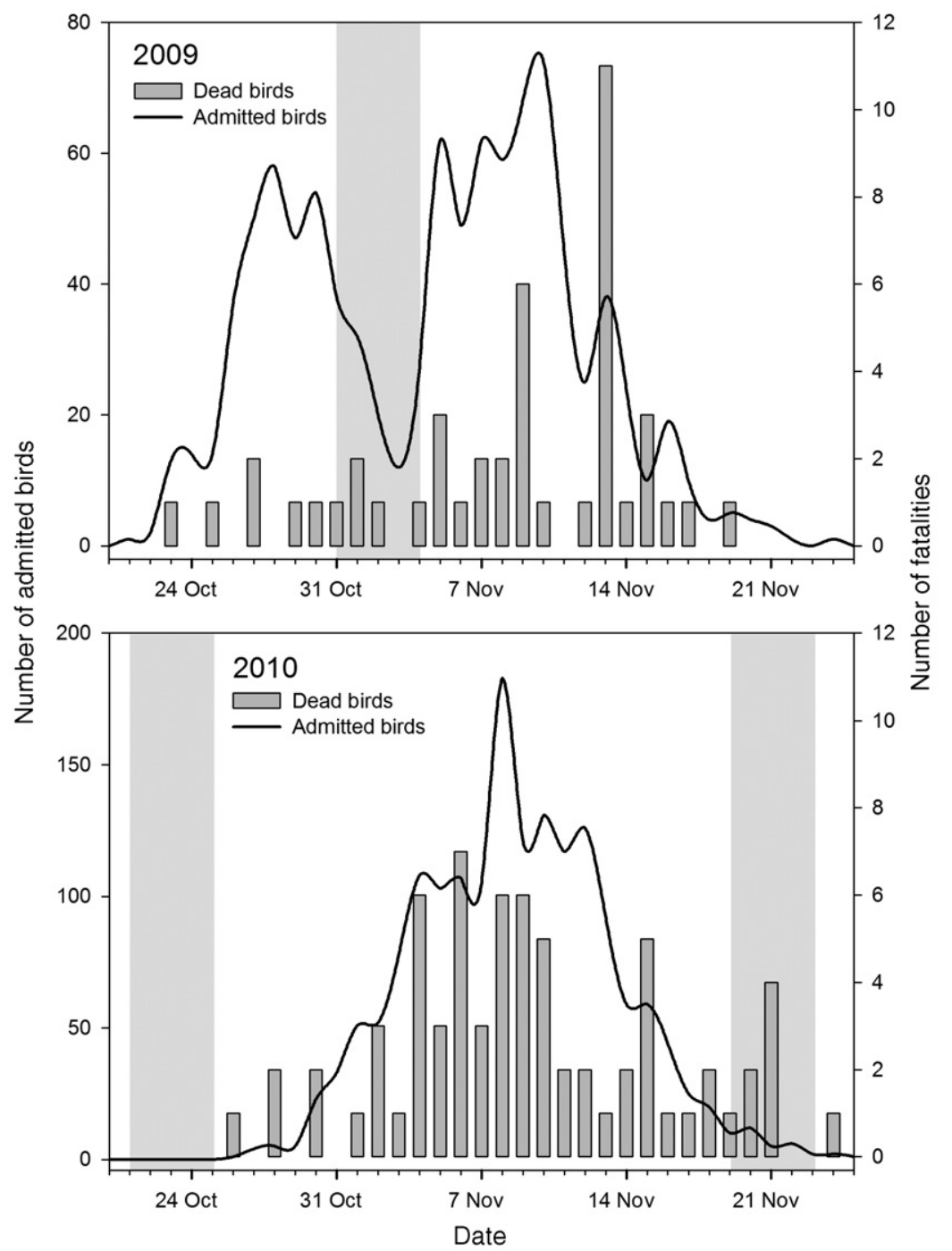

Figure 2 Daily distribution of stranded Cory's Shearwater Calonectris diomedea fledglings during the 2009 and 2010 fallouts on Tenerife, Canary Islands. The shaded area indicates a full moon ! 2 days. period, we constructed a full factorial general linear model with year, status and sex as categorical fixed factors and date (Julian date) as a covariate. Logistic regression models (with binomial errors and a logit link function) were employed to analyze the probability of rescuing a particular sex according to year, status and date, and the probability of rescue of successfully released birds according to year, sex, body condition, date and down index.

Except for the reduced major axis regression necessary to calculate the scaled mass index, which was done using RMA v.1.17 software for Windows (San Diego State University, San Diego, CA, USA) (Bohanak \& van der Linde, 2004), statistical analyses were conducted in SPSS Statistics v. 19.0 (IBM Company, Chicago, IL, USA).

\section{Results}

In Tenerife, 2749 fledglings were admitted by the La Tahonilla WRC (984 and 1765 in 2009 and 2010, respectively; $c^{2}=221.8, P<0.001$; Fig. 2). Ninety-two individuals were found dead or had to be euthanized (22 and 70 in 2009 and 2010, respectively). In Valle de Güímar, 265 fledglings were rescued (97 and 168 birds in 2009 and 2010, respectively; $\left.c^{2}=19.0, P<0.001\right)$.

\section{Body condition}

BCI correlated significantly and negatively to date (Fig. 3). The variables 'year', 'status', 'sex' and 'down index' were not significant (Table 1), as well as the ‘sex $¥$ year’ and ‘sex $¥$ date’ interactions (both $P$-values $>0.401$ ). The majority of stranded fledglings (45.1\%) had no visible down (Fig. 4). The frequency of down index categories did not vary between successfully released birds and dead ones $\left(G_{4}=7.407, P=0.116\right)$, but it reached marginal significance between sexes and years $\left(G_{4}=9.502, P=0.050\right.$ and $G_{4}=9.104, P=0.059$, respectively). The down index did 


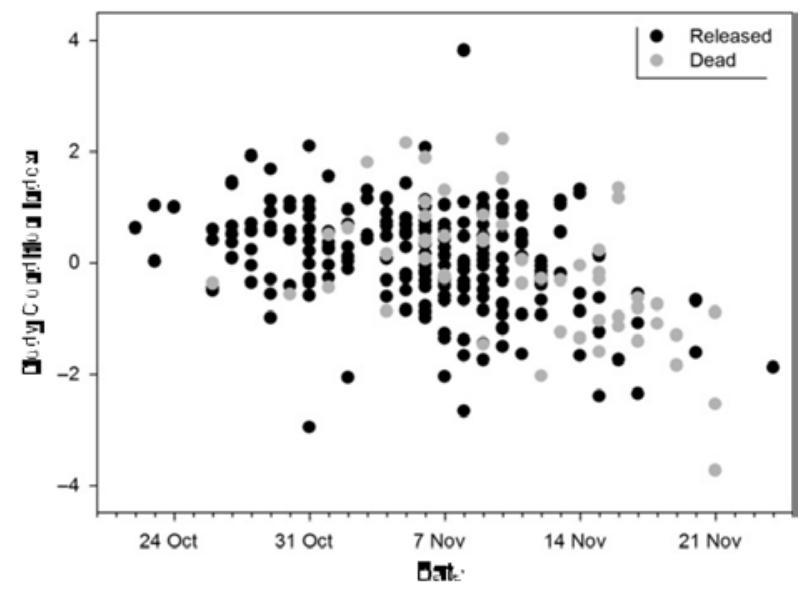

Figure 3 Relationship between date and body condition index (standardized residuals of an ordinary least square regression of body mass on body size index) of both released and dead fledglings.

not correlate with BCI $\left(r_{\mathrm{s}}=0.102, P=0.092\right)$ or with date $\left(r_{\mathrm{s}}=-0.001, P=0.981\right)$.

\section{Sex ratio}

Apart from the 196 fledglings that we sexed molecularly, we sexed 77 additional fledglings applying the discriminant function $=0.782(\mathrm{BD})+0.381(\mathrm{BL})+0.202(\mathrm{~T})-42.886$, which correctly discriminated $90 \%$ of birds (see Supporting Information Appendix S1). Thus, one would expect eight misassignments in the 77 morphometrically sexed birds. For this reason, we conducted separate analyses for the two datasets: one containing only genetically sexed birds and another one containing genetically and morphometrically sexed birds. Overall, the rescued birds were not sex biased for genetically or morphometrically sexed birds (100 females vs. 96 males; $c^{2}=0.082, P=0.775$; and 36 females vs. 41 males; $c^{2}=0.325, P=0.568$, respectively), and the results did not differ between datasets. In addition, no differences were detected in the sex ratio according to type of sex determination (genetic vs. discriminant function; $G=0.163$, $P=0.686$ ). For all of the above, we only show the results for the larger dataset. Likelihood ratio tests showed no differences in the sex ratio between years (2009 vs. 2010; $G=0.006, P=0.940$ ) or status (released vs. dead; $G=0.001$, $P=0.974)$. The logistic regression model to explore the effect of year, status and date on the probability of rescue of each sex did not include any significant term (Table 1).

\section{Fate of rescued birds}

The probability of releasing back to the wild a rescued fledgling decreased with rescue date and abundance of down in head and belly, but it was not explained by body condition (Table 1).

\section{Discussion}

\section{Condition and sex of stranded birds}

We have evaluated for the first time the factors affecting both body condition and sex ratio of fledgling shearwaters stranded by light pollution. We found that body condition of Cory's Shearwater fledglings decreased during the fallout

Table 1 Results of a general linear model and binary logistic regressions for body condition index, sex ratio and status variations in relation to year, date, sex and down index

\begin{tabular}{|c|c|c|c|c|}
\hline Dependent variable & Model & Estimate 【 SE & Statistic (F or Wald) & $P$ \\
\hline \multirow[t]{7}{*}{ Body condition } & General linear model & & & \\
\hline & Intercept & 2480.275 ! 394.394 & 39.552 & $<0.001$ \\
\hline & Year $^{\mathrm{a}}$ & 0.156 ! 0.120 & 1.693 & 0.194 \\
\hline & Status $^{a}$ & 0.101 】 0.149 & 0.459 & 0.499 \\
\hline & $\operatorname{Sex}^{a}$ & 0.098 【 0.115 & 0.732 & 0.393 \\
\hline & Julian date & -0.061 】 0.010 & 39.553 & $<0.001$ \\
\hline & Down index & 0.011 【 0.043 & 0.065 & 0.799 \\
\hline \multirow[t]{5}{*}{ Sex } & Logistic regression & & & \\
\hline & Intercept & 673.832 【 863.079 & 0.610 & 0.435 \\
\hline & Year $^{a}$ & 0.013 ! 0.259 & 0.002 & 0.960 \\
\hline & Status $^{a}$ & 0.073 【 0.322 & 0.051 & 0.822 \\
\hline & Julian date & $-0.016 \leq 0.021$ & 0.610 & 0.435 \\
\hline \multirow[t]{7}{*}{ Status } & Logistic regression & & & \\
\hline & Intercept & 6493.352 ! 1418.592 & 20.364 & $<0.001$ \\
\hline & Year $^{\mathrm{a}}$ & 0.748 【 0.381 & 3.206 & 0.073 \\
\hline & Sex $^{a}$ & 0.284 【 0.343 & 0.529 & 0.408 \\
\hline & Body condition & -0.166 】 0.179 & 1.020 & 0.354 \\
\hline & Julian date & -0.159 】 0.035 & 20.353 & $<0.001$ \\
\hline & Down index & -0.298 】 0.121 & 6.016 & 0.014 \\
\hline
\end{tabular}

Significant $P$-values are in bold.

aParameter estimates were calculated considering a reference value of zero for '2010', 'released' and 'male' levels. SE, standard error. 

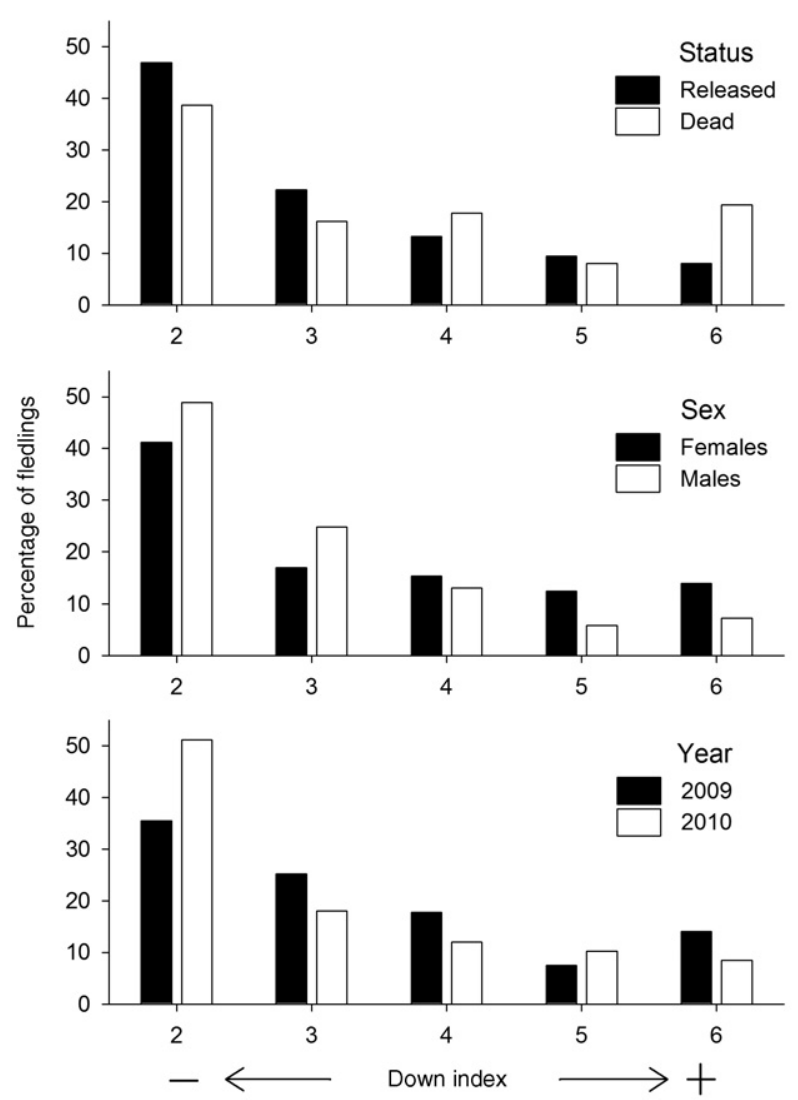

Figure 4 Differences in the down index of Cory's Shearwater Calonectris diomedea stranded fledglings among status, sex and year.

period (Fig. 3). The worsening of body condition seems obvious given that parental food delivery and feeding frequency decrease sharply at the end of the chick-rearing period (Ramos et al., 2003), and consequently fledglings loose about 28-40 g daily (Zino et al., 1987; Mougin et al., $2000 b$ ). Given the remarkable sexual size dimorphism of the species (Thibault et al., 1997; see Supporting Information Appendix S1), one would expect a greater sensitivity of male chicks to adverse conditions (Genovart et al., 2005). However, and despite parental food delivery being less frequent on full-moon nights (Klomp \& Furness, 1992; Riou \& Hamer, 2008; but see also Granadeiro et al., 1998, 2009; Mougin et al., 2000a), we did not detect differences in body condition between sexes in two fallouts differing in moon phases (Fig. 2). Interestingly, the body condition indices of successfully released birds was similar to those of fatally attracted birds, and the probability of successfully releasing a bird did not depend on its body condition, suggesting that light-induced mortality do not differentially affect birds in good or bad condition. We have to note that these results are conservative given that the 'fatally attracted birds' category includes birds that could be rescued several days after the birds got stranded, although observing the tail of accumulated birds during the nine fallouts, this does not seem to affect many fledglings (Fig. 3A in Rodríguez \& Rodríguez, 2009).

In addition, down index (a surrogate of actual age or development at the time of leaving the nest) did not explain body condition of fledglings, but the probability of successfully releasing a bird decreased with the abundance of down in its head and belly. Thus, if we assumed, as stated above, that down index is a proxy of age, then the younger birds at the end of the fledging period are more susceptible to be fatally affected by light pollution. Additional non-mutually exclusive explanations may be that down negatively affects the aerodynamic, flight capacities of fledglings being diminished, or that down abundance is an indicator of plumage development; thus, fledglings with a high abundance of down have not developed wholly their plumage. On the other hand, the probability of successfully releasing a bird was negatively related with date. This suggests that later birds are somehow forced to fly at the end of fledging period and do it when they are not fully grown.

We failed to detect sex-biased stranding of fledglings in our study. The only previously available information on the sex ratio of petrels stranded by light pollution is based on adult Newell's Shearwaters Puffinus newelli on Kauai, Hawaiian archipelago, where an unbiased sex ratio was reported, although it was based on a much smaller sample size (30 birds, males: females ratio $=8: 9$; Ainley et al., 2001). For Cory's Shearwater fledglings, sex ratio appears to be equal to parity (Genovart et al., 2005), although a male biased sex ratio has been reported in a Mediterranean colony using morphometric discriminant functions and sexual dimorphism in voice, and therefore results should be taken with caution (Bretagnolle \& Thibault, 1995). Assuming that offspring sex ratio at fledging does not differ from parity (Genovart et al., 2005; but see Bretagnolle \& Thibault, 1995), our results indicate that both sexes have the same probability to be attracted to artificial lights as well as to be fatally injured.

\section{Implications for design of rescue campaigns and future research}

The life expectancy of rescued birds as well as their recruitment rate into the breeding population is currently unknown. The fledging body mass is likely to play a crucial role in their subsequent survival at sea (Mougin et al., $2000 b$ ). Given the worsening in body condition through the fledging period, an effort should be done to try to rescue birds as soon as they fall and, if veterinary care is not required, to release them immediately. In addition, an enhancement of rescue campaigns during the early stage of fledging is justified (e.g. a more intensive search of grounded fledglings), as fully grown birds with perhaps higher survival prospects in the long-term are involved in the fallout. During the last part of the fledging period when more fatal collisions occur (Fig. 3), a higher effort in the veterinary care should be done (providing food and liquid), especially for fledglings more susceptible to death (i.e. those showing abundant down). 
The first weeks following the fledging period are probably difficult for individuals who never before searched for food by themselves. The flapping flights around artificial lights may be too costly for soaring birds like shearwaters. These flights may last for several hours until birds become apparently exhausted and stunned, and crash into human-made structures, such as buildings, wires, electricity pylons or even vehicles. Although it is hard to get a reasonable sample size of control fledglings (i.e. ungrounded fledglings) to assess the effect of these flights on fledgling body condition, it should be a priority to determine the actual effects of light pollution on the critical fledging stage in the life of petrels. Abundance of down is another topic that deserves further study. Specifically, it is necessary to assess its effect on flight performance, waterproofing or insulation of plumage at the sea, and its relation with plumage development.

It is well known that the full moon has an important effect on the number of petrels grounded (Reed et al., 1985; Telfer et al., 1987; Le Corre et al., 2002; Salamolard et al., 2007; Rodríguez \& Rodríguez, 2009; Miles et al., 2010), as fewer fledglings are rescued during years when a full moon overlaps with the fledging peak (Ainley et al., 2001; Rodríguez et al., 2012; this study). Thus, we can predict how the fallout pattern will be, allowing managers to make optimal decisions on rescue efforts and personnel deployment. Other massive artificial light-induced mortalities of not only passerines but also insects and sea turtles are related to the new moon, suggesting that the same factors may be acting on divergent taxonomical groups (Verheijen, 1981; Salmon \& Witherington, 1995; Rich \& Longcore, 2006). Therefore, further research into the effect of moon phases could help minimize light-induced mortality of vast numbers of nocturnal animals irrespective of their taxonomical group.

\section{Acknowledgements}

We are deeply thankful to all the anonymous people who kindly helped rescuing the birds. We are indebted to the staffs of Grupo de Pronto Auxilio de Arafo, Centro de Recuperación de Fauna Silvestre La Tahonilla (Cabildo de Tenerife), Oficina de Voluntariado Ambiental (Cabildo de Tenerife) and local police for their help and collaboration in different ways during the rescue campaigns. We thank Juli Broggi, David G. Ainley, Todd Katzner and one anonymous reviewer for their constructive comments on early drafts of this manuscript. A.R. was supported by an I3P pre-doctoral fellowship from the Consejo Superior de Investigaciones Científicas.

\section{References}

Ainley, D.G., Podolsky, R., Nur, N., Deforest, L. \& Spencer, G.A. (2001). Status and population trends of the Newell's Shearwater on Kauai: a model for threatened petrels on urbanized tropical oceanic islands. Stud. Avian Biol. 22, 108-123.
Baccetti, N., Sposimo, P. \& Giannini, F. (2005). Artificial lights and mortality of Cory's shearwater Calonectris diomedea on a Mediterranean island. Avocetta 29, 89-91.

Bohanak, A. \& van der Linde, K. (2004). RMA: software for reduced major axis regression, Windows version. http://www.bio.sdsu.edu/pub/andy/RMA.html. (accessed 2 January 2011).

Bourgeois, S., Gilot-Fromont, E., Viallefont, A., Boussamba, F. \& Deem, S.L. (2009). Influence of artificial lights, logs and erosion on leatherback sea turtle hatchling orientation at Pongara National Park, Gabon. Biol. Conserv. 142, 85-93.

Bretagnolle, V. \& Thibault, J.-C. (1995). Method for sexing fledglings in Cory's shearwaters and comments on sexratio variation. Auk 112, 785-790.

Cockburn, A., Legge, S. \& Double, M.C. (2002). Sex ratios in birds and mammals: can the hypotheses be disentangled. In Sex ratios, concepts and research methods: 266286. Hardy, I.C.W. (Ed.). Cambridge: Cambridge University Press.

Donald, P.F. (2007). Adult sex ratios in wild bird populations. Ibis 149, 671-692.

Duffy, D.C. (2010). Changing seabird management in Hawai'i: from exploitation through management to restoration. Waterbirds 33, 193-207.

Ferrer, M., Newton, I. \& Pandolfi, M. (2009). Small populations and offspring sex-ratio deviations in eagles. Conserv. Biol. 23, 1017-1025.

Fontaine, R., Gimenez, O. \& Bried, J. (2011). The impact of introduced predators, light-induced mortality of fledglings and poaching on the dynamics of the Cory's shearwater (Calonectris diomedea) population from the Azores, northeastern subtropical Atlantic. Biol. Conserv. 144, 1998-2011.

Fridolfsson, A.K. \& Ellegren, H. (1999). A simple and universal method for molecular sexing of non-ratite birds. J. Avian Biol. 30, 116-121.

Genovart, M., Oro, D., Forero, M.G., Igual, J.M., González-Solís, J. \& Ruiz, X. (2005). Parental body condition does not correlate with offspring sex ratio in Cory's shearwaters. Condor 107, 161-167.

González-Solís, J., Croxall, J.P., Oro, D. \& Ruiz, X. (2007). Trans-equatorial migration and mixing in the wintering areas of a pelagic seabird. Front. Ecol. Environ. 5, 297301.

Granadeiro, J.P., Alonso, H., Almada, V., Menezes, D., Phillips, R.A. \& Catry, P. (2009). Mysterious attendance cycles in Cory's shearwater, Calonectris diomedea: an exploration of patterns and hypotheses. Anim. Behav. 78, 1455-1462.

Granadeiro, J.P., Burns, M.D. \& Furness, R.W. (1998). Patterns of activity and burrow attendance in Cory's Shearwater Calonectris diomedea as revealed by a novel logging technique. Ibis 140, 458-466. 
Green, A.J. (2001). Mass/length residuals: measures of body condition or generators of spurious results. Ecology 82, 1473-1483.

Hölker, F., Moss, T., Griefahn, B., Kloas, W., Voigt, C.C., Henckel, D., Hänel, A., Kappeler, P.M., Völker, S., Schwope, A., Franke, S., Uhrlandt, D., Fischer, J., Wolter, C. \& Tockner, K. (2010a). The dark side of light: a transdiciplinary research agenda for light pollution policy. Ecol. Soc. 15, 13.

Hölker, F., Wolter, C., Perkin, E.K. \& Tockner, K. (2010b). Light pollution as a biodiversity threat. Trends Ecol. Evol. 25, 681-682.

Horváth, M.B., Martinez-Cruz, B., Negro, J.J., Kalmar, L. \& Godoy, J.A. (2005). An overlooked DNA source for non-invasive genetic analysis in birds. J. Avian Biol. 36, 84-88.

Imber, M.J. (1975). Behaviour of petrels in relation to the moon and artificial lights. Notornis 22, 302-306.

ISTAC (2011). Instituto Canario de Estadística. Gobierno de Canarias. http://www.gobiernodecanarias.org/istac. (accessed 10 January 2011).

Jones, J. \& Francis, C.M. (2003). The effects of light characteristics on avian mortality at lighthouses. J. Avian Biol. 34, 328-333.

Kalmbach, E. \& Benito, M.M. (2007). Sexual size dimorphism and offspring vulnerability in birds. In Sex, size, and gender roles, evolutionary studies of sexual size dimorphism: 133-142. Fairbairn, D.J., Blanckenhorn, W.U. \& Székely, T. (Eds). Oxford: Oxford University Press.

Kempenaers, B., Borgström, P., Löes, P., Schlicht, E. \& Valcu, M. (2010). Artificial night lighting affects dawn song, extra-pair siring success, and lay date in songbirds. Curr. Biol. 20, 1735-1739.

Klomp, N.I. \& Furness, R.W. (1992). Patterns of chick feeding in Cory's shearwaters and the associations with ambient light. Colon. Waterbirds 15, 95102.

Le Corre, M., Ghestemme, T., Salamolard, M. \& Couzi, F.-X. (2003). Rescue of the Mascarene Petrel, a critically endangered seabird of Reúnion Island, Indian Ocean. Condor 105, 387-391.

Le Corre, M., Ollivier, A., Ribes, S. \& Jouventin, P. (2002). Light-induced mortality of petrels: a 4-year study from Réunion Island (Indian Ocean). Biol. Conserv. 105, 93-102.

Longcore, T. \& Rich, C. (2004). Ecological light pollution. Front. Ecol. Environ. 2, 191-198.

Miles, W., Money, S., Luxmoore, R. \& Furness, R.W. (2010). Effects of artificial lights and moonlight on petrels at St Kilda. Bird Study 57, 244-251.

Mougin, J.-L., Jouanin, C. \& Roux, F. (2000a). The attendance cycles of Cory's Shearwater Calonectris diomedea borealis on Selvagem Grande. C. R. Acad. Sci. III-Vie 323, 385-390.
Mougin, J.-L., Jouanin, C., Roux, F. \& Zino, F. (2000b). Fledging weight and juvenile survival of Cory's shearwater Calonectris diomedea on Salvagem Grande. Ring. Migrat. 20, 107-110.

Peig, J. \& Green, A.J. (2009). New perspectives for estimating body condition from mass/length data: the scaled mass index as an alternative method. Oikos 118, 1883-1891.

Peig, J. \& Green, A.J. (2010). The paradigm of body condition: a critical reappraisal of current methods based on mass and length. Funct. Ecol. 24, 13231332.

Poot, H., Ens, B.J., de Vries, H., Donners, M.A.H., Wernand, M.R. \& Marquenie, J.M. (2008). Green light for nocturnally migrating birds. Ecol. Soc. 13, 47.

Ramos, J.A., Moniz, Z., Solá, E. \& Monteiro, L.R. (2003). Reproductive measures and chick provisioning of Cory's Shearwater Calonectris diomedea borealis in the Azores. Bird Study 50, 47-54.

Reed, J.R., Sincock, J.L. \& Hailman, J.P. (1985). Light attraction in endangered procellariiform birds: reduction by shielding upward radiation. Auk 102, 377-383.

Rich, C. \& Longcore, T. (Eds) (2006). Ecological consequences of artificial night lighting. Washington, DC: Island Press.

Riou, S. \& Hamer, K.C. (2008). Predation risk and reproductive effort: impacts of moonlight on food provisioning and chick growth in Manx shearwaters. Anim. Behav. 76, 1743-1748.

Robertson, B.C., Elliott, G.P., Eason, D.K., Clout, M.N. \& Gemmell, N.J. (2006). Sex allocation theory aids species conservation. Biol. Lett. 2, 229-231.

Rodrigues, P., Aubrecht, C., Gil, A., Longcore, T. \& Elvidge, C. (2012). Remote sensing to map influence of light pollution on Cory's shearwater in São Miguel Island, Azores Archipelago. Eur. J. Wildl. Res. 58, 147-155.

Rodríguez, A. \& Rodríguez, B. (2009). Attraction of petrels to artificial lights in the Canary Islands: effect of the moon phase and age class. Ibis 151, 299-310.

Rodríguez, A., Rodríguez, B., Barone, R., Pérez, B. \& Hernández, A. (2008). Status and conservation requirements of Manx Shearwaters Puffinus puffinus on Tenerife (Canary Islands). Alauda 76, 72-74.

Rodríguez, A., Rodríguez, B. \& Lucas, M.P. (2012). Trends in numbers of petrels attracted to artificial lights suggest population declines in Tenerife, Canary Islands. Ibis 154, 167-172.

Salamolard, M., Ghestemme, T., Couzi, F.-X., Minatchy, N. \& Le Corre, M. (2007). Impacts des éclairages urbains sur les petrels de Barau, Pterodroma baraui sur I'lle de la Réunion et measures pour réduire ces impacts. Ostrich 78, 449-452. 
Salmon, M. \& Witherington, B.E. (1995). Artificial lighting and seafinding by loggerhead hatchlings: evidence for lunar modulation. Copeia 4, 931-938.

Stone, E.L., Jones, G. \& Harris, S. (2009). Street lighting disturbs commuting bats. Curr. Biol. 19, 1123-1127.

Telfer, T.C., Sincock, J.L., Byrd, G.V. \& Reed, J.R. (1987). Attraction of Hawaiian seabirds to lights: conservation efforts and effects of moon phase. Wildl. Soc. Bull. 15, 406-413.

Tella, J.L. (2001). Sex-ratio theory in conservation biology. Trends Ecol. Evol. 16, 76-77.

Thibault, J.-C., Bretagnolle, V. \& Rabouam, C. (1997). Calonectris diomedea Cory's Shearwater. BWP Update 1, 75-98.

Truett, G.E. (2006). Preparation of genomic DNA from animal tissues. In DNA sequencing II: optimizing preparation and cleanup: 33-46. Kieleczawa, J. (Ed.). Sudbury: Jones and Bartlett.

Verheijen, F.J. (1981). Bird kills at tall lighted structures in the USA in the period 1935-1973 and kills at a Dutch lighthouse in the period 1924-1928 show similar lunar periodicity. Ardea 69, 199-203.
Warham, J. (1990). The petrels: their ecology and breeding systems. London: Academic Press.

Zino, P.A., Zino, F., Maul, T. \& Biscoito, J.M. (1987). The laying, incubation and fledging periods of Cory's shearwater Calonectris diomedea borealis on Selvagem Grande in 1984. Ibis 129, 393-398.

\section{Supporting information}

Additional Supporting Information may be found in the online version of this article:

Appendix S1 Sexual discriminant function analyses for Cory's Shearwater Calonectris diomedea borealis fledglings stranded by light pollution.

Please note: Wiley-Blackwell are not responsible for the content or functionality of any supporting materials supplied by the authors. Any queries (other than missing material) should be directed to the corresponding author for the article. 